\title{
Bringing history into the study of routines: contextualizing performance
}

\section{Abstract}

The focus on routines as 'generative systems' often portrays them as patterns of action relatively divorced from their context. History can help to supply a deeper and richer context, showing how routines are connected to broader structural and cultural factors. But it also shows that routines themselves have a history. This is explored using the illustration of the history of one particular organizational routine, that of the visitation of local organizational units by central church bodies, in three times and places: fifteenth century Italy, eighteenth century England and eighteenth century Scotland. This illustration shows that similar routines can be found but these are given very different inflections by the broader social, cultural and political context. Attention is drawn in particular to the differential involvement of lay actors and the implications for broader impacts. The case is made for analytical narratives of emergence of routines which can reconnect organizational routines both with their own history and with their broader context.

\section{Keywords}

Organizational routines, morphogenesis, religion, analytical narrative, history

\section{Acknowledgments}

My thanks to the archivists who facilitated this research, especially Robin Urquhart of the National Records of Scotland. The ideas developed here owe a great deal to the excellent discussions at the standing working group on history at the colloquia of the European Group for Organization Studies. 
Much of the work on organizational routines has argued for their role as 'generative systems', promoting organizational change (Feldman 2000; Feldman \& Rafaeli 2002; Feldman and Pentland, 2003; Pentland \& Feldman 2005; Pentland \& Feldman 2008). The focus on 'routine dynamics' has seen a shift towards forms of process theory, theory which emphasises fluidity, movement and creativity (Helin et al, 2014). However, it is arguable that such a shift tends to tear routines out of their broader context. An examination of routines in history suggests both that routines themselves have a history, that is, they are not created $a b$ initio but draw on existing templates, and that they are linked to broader bodies of ideas and resources which shape their form. This contention is developed through the comparative study of one particular routine in different contexts. This routine is the visitation in organized Christian churches. By 'visitation' is meant the inspection of local affairs by an officially constituted body of the wider church, following rules which have their ultimate root, however mediated by other factors, in theological commitments. This article has its origins in the historical study of organized religion, where the examination of routines is enormously valuable as it qualifies and enriches approaches based simply on belief as expressed in formal theological statements. But that same study indicates more stability to routines and more connections to the wider context than the focus on routines as performance would suggest. A historical approach to routines, therefore, is not only of interest for what it tells us about the past; it can also illuminate contemporary routines and perhaps rebalance our theorizing of them away from too great a focus on performance.

The article opens with an outline of work on organizational routines with a focus on the notion of routines as generative mechanisms as pioneered by Feldman and Pentland. Some concerns about this approach from those exploring routines are presented, highlighting the 
use of the work of the historian William Sewell as one alternative formulation.

Conceptualizing history as providing 'analytical narratives of emergence' suggests that a historical approach is valuable in showing how routines might change and adapt in the face of changing circumstances. It can also indicate how either routines with the same label have differing content or how similar circumstances call forth performances which have echoes of partially forgotten routines. A focus on one specific practice, the routine of the visitation, draws our attention to the importance of examining the relationship between bodies of ideas, practices and social groupings. The importance of lay involvement as a diffusion mechanism for ideas from the religious to the economic domain is stressed.

\section{Routines as performance: some concerns}

Routines are far from encompassing the full gamut of practices, although for some there is the danger that that is how they are seen (Felin and Foss, 2009: 159). They are one analytical device for bringing out the mundane and taken for granted in organizing (Nicolini, 2009). In the context of the religious life that will form the focus of this article, they are a useful device to distinguish certain practices from those which can be labelled as rituals (Clark, 2004). Even accepting the utility of this distinction, it is recognized that there are competing conceptualisations of routines, some of which are drawn on as the discussion unfolds (Becker, 2008; Becker and Lazeric, 2009). However, we start from one particularly influential stream of work, that most closely associated with the work of Martha Feldman and Brian Pentland. Here routines are defined as, 'repetitive, recocognizable patterns of interdependent actions, carried out by multiple actors' (Feldman and Pentland, 2003: 950). A key focus in their various articles is the stress on agency. Routines are not just abstract sets of instructions; they are performed. This means that they are, 'not only effortful but 
also emergent accomplishments. They are often works in progress rather than finished products' (Feldman, 2000: 613). Given this perspective, those who perform the routines, it is argued, are not blind rule followers but active selectors from a menu of possibilities, 'from which organizational members enact particular performances' (Feldman, 2000: 612). These aspects of action are then related to a key distinction, which is that between the 'ostensive' and the 'performative' aspects of routines. The ostensive aspects of the routine are the 'abstract idea of the routine', while the performative relates to, 'the actual performances of the routine by specific people, at specific times, in specific places' (Feldman \& Pentland, 2003: 95). This is clearly not the only approach to organizational routines, as we will note below, but it is a perspective which has spawned a considerable amount of work, hence it is the starting point for our consideration.

While the work produced has been of considerable interest and value, it is open to a number of critiques. These, which I consider in turn, are that there is a focus on the unique which tends to downplay the degree of repetition inherent in routines; that the meaning of routines is collapsed into the performance of routines, as opposed to being relatively enduring conceptions which form resources which can be drawn upon; and that routines are detached from the broader forces shaping their nature and performance. It seems a fairly fundamental critique that we lose a sense of the 'routineness' of routines (Birnholtz et al, 2009). That is, an everyday use, as expressed in dictionary definitions, would stress the rote aspects of routines. Thus the Oxford English Dictionary (2011) has as its primary usage the following: 'A regularly followed procedure; an established or prescribed way of doing something; a more or less mechanical or unvarying way of performing certain actions or duties.' It is, of course, this focus on the predictability and stability of routines that 
characterised the conceptualisation of routines in the economics literature, notably the work of Nelson and Winter (1982) that the generative systems approach has reacted to. In the process, however, that focus on the 'more or less mechanical' is lost in the attention to the creative performance of routines. The second is that the meaning of routines, the 'ostensive' in Feldman and Pentland's terms, tends to be collapsed into the ideas generated during the performance of those routines (Rerup and Feldman, 2011; Dionysiou and Tsoukas, 2013). Wright (2014) has taken this to one logical conclusion. In an insightful critique of the derivation of the distinction between ostensive and performative, he argues that routines ought to be seen in a framework supplied by the notion of the communicative constitution of organizations. In this move, routines are collapsed into the ongoing processes of organizing.

This is problematic in two senses. One is that we lose the connection with the wider organization. The second is that the way in which participants might draw upon broader resources in framing their actions is even less clear. The first problem has received some attention, albeit somewhat muted, in the literature. In a study of conflict over a pricing routine, for example, Zbaracki and Bergen (2010) show how the marketing function were able to deploy ideas drawn from formal pricing theory as a powerful counter to the more experiential arguments of the sales function. It was not that the formal pricing theories were used, but that, '...whereas the sales force tended to focus on concrete pricing terms, the marketing group offered a more abstract language rooted in economics' (Zbaracki and Bergen, 2010: 968). As they note, 'jurisdictional battles reflect political, institutional and cognitive forces drawn from macrosocial battles' (Zbaracki and Bergen, 2010: 968). In similar fashion, Essén (2008), in a study of Swedish homecare routines, points to the way in which 
routines are put into practice through the deployment of cultural norms that exceed and come from outside the genesis of formal rules.

Zbaracki and Bergen point to struggles over the nature of routines between particular organizational groups, groups which obtain their standing from organizational arrangements. A similar clash is reported by D'Adderio (2008) in her study of the impact of software in a manufacturing company. Her language here is that of 'occupational community', but this points to differences engendered by the particular forms of organizational structuring of expertise. D'Adderio speaks of management as a particular form of community, which rather tends to underplay the significance of hierarchical position in conditioning the nature of routines. This aspect of power in organizations is better addressed, albeit briefly, by Howard-Grenville's study of the use of a particular decision technique in a computer hardware fabrication company. She notes here that ...in all cases the individuals with greater command over the resources will be better able to change embedded routines over time. Changing routines that are strongly embedded in cultural structures may rely heavily on the use of authoritative and relational resources because they can be used to frame and negotiate, over time, shared meaning, shared norms, and collective identity (Howard-Grenville, 2005: 634).

In a study of waste management organizations, Turner and Rindova (2012) show how particular artifacts, such as scheduling techniques, were used to prepare detailed guides for action, such as collection routes. Not only were everyday routines tightly conceived and executed, but routines for managing exceptions, although by necessity looser, were in place. Such artifacts, 'are largely introduced by the organization and reflect the management's 
view of how the routine should function' (Turner and Rindova, 2012: 42). These examples suggest that organizational routines are not just emergent from action but are shaped by organizational structures. As Ventresca and Kaghan argue

We draw particular attention to the importance of bureaucratic processes, managerial work, and their relation to organizational stability and change. We underscore the importance of resisting efforts to separate analytically (whether by initial assumption or by research design) the performance of routine activity from the supporting social structures and meanings (Ventresca and Kaghan , 2008, 55-6).

However, their advice is generally ignored in the mainstream of work on organizational routines, with the broader context, extending to the existence of rules, bracketed out. Of course, those rules can never provide an exhaustive guide to performance and, as Essén (2008) shows, actors draw upon their own experience and broader cultural norms to produce an effective performance. However, she also shows how participants often welcome rules as a framework for action. Regardless of the response of participants, there is a powerful incentive, Ingvaldson (2015) argues, for managers to seek to codify practices in the name of consistency and transferability. That such efforts are bound to be only partially successful does not mean that the efforts are insignificant in their impacts (Reynaud, 2005). As D'Adderio points out that

formal procedures and rules can always - in theory - be worked around and dismissed, in practice they often play a role. Especially when embedded in artefacts such as software, and/or entangled into thick organisational interrelationships, they become visible, pervasive, difficult to change or avoid, easier to enforce (D'Adderio, 2008: 784). 
These problems - the focus on the creative rather than the repetitious, the collapsing of meanings into those arising during performance and the lack of connection to broader shaping conditions - can be addressed, this article claims, by bringing in historical perspectives. In particular, the exploration of routines as part of an analytical narrative of emergence (Archer 1995) can help to supply that broader context which balances the focus on individual performance which increasingly marks the literature (Felin and Foss, 2009; Friesl and Larty, 2012).

\section{The value of history}

One opening to the value of history is supplied by Howard-Grenville's (2005) formulation of routines as embedded in broader structures noted above. This draws on the work of the historian William Sewell. Sewell is a cultural historian who has taken a particular interest in bridging the gap between historical and social theory, seeking to work back and forth between each to enrich both (Sewell, 2005). Sewell's work is occasionally mentioned in passing in the organizational literature, without appreciation of the way in which it is grounded in historical work. It is this historical perspective that led Sewell to question the formulation of rules and resources as 'virtual'. In his critique of this approach, Sewell allows that what he would term 'schema' can be conceived of as virtual, but that the status of resources is more problematic in that some clearly take material form. 'Factories, land, and Hudson Bay blankets,' he argues, 'have material qualities that are certainly not generated by schemas' (Sewell, 2005: 135). In turn, what makes these material properties count as particular types of resources depends on enduring rules. So, for example, the, 'resources gained by peasants from the land they use will be determined by the conventions of land tenure, the exigencies of customary law, the sets of obligations owed to kinsmen, and the 
agricultural techniques employed' (Sewell, 2005: 135). Now, some of these rules are flexible and emergent from practice, but others are more enduring. They confront actors as the situational logics which condition their actions, thus emphasising the enduring nature of both material and cultural structures.

Sewell's explicit attention to concept formation and definition is comparatively unusual amongst historians. It supports calls for what Archer (1995) terms 'analytical narratives of emergence'. Here phenomena, such as routines, are seen as emergent from particular situational logics, which condition but do not determine, the shape and nature of those phenomena. Hence time is crucial, but this is not time as a variable, constituted of interchangeable and reversible units. Rather time shapes the nature of phenomena, setting them on paths which, once entered on, are relatively enduring. Narratives are then central to plotting this emergence, but also in recognising the importance of contingency. Accident, that is, can play a role in confounding the playing out of forces which otherwise might be seen as having an unfolding logic. However, this is not narrative as the simple plotting of a number of events in chronological order. There is the recognition that history has a double meaning: it is both what has happened and the representation of that happening (Rowlinson, Hassard and, Decker 2015). The latter necessarily involves selection and in analytical narratives there is an explicit focus on particular concepts. Examples of such analytical narratives of emergence in the work of social theorists, although not necessarily labelled as such, are provided by Margaret Archer, Norbert Elias and Michel Foucault.

Archer's (1979) work on educational systems plots, over a three-hundred year period, the fate of educational reforms in four different systems. These systems were deliberately chosen for comparative analytical purposes because of the degree of centralisation that 
they exhibited: England and Denmark as examples of more decentralised polities, France and Russia standing for more centralised polities. Examining several cycles of action, she shows how similar initiatives met with very different fates in the different contexts, thus drawing our attention to the importance of cultural and material contexts. Elias (2000), by contrast, has more focus on mundane practices but uses examples of those over the transition from the medieval to the early modern periods to show the growth of 'civilizing' practices. That is, quotidian practices of eating, such as the emergence and use of the fork, pioneered by the nobility but spreading by emulation through all social classes, constituted, over time, new norms of acting and behaving in social situations. Although Michel Foucault explicitly renounced the description of his work as that of a historian, he did use extensive historical material in his focus on religion as social practice, an approach of relevance to the empirical section of this article (Foucault, 1997). Specifically, he examined the practice of auricular confession as it developed within the Roman Catholic church over the Middle Ages in its contribution to what he termed 'pastoral power' (Mutch, 2015b). Here we have an example of how enduring sets of ideas shaped practices which persisted over time and which took their meaning from those broader ideas. If we turn this lens on one of the early and classic formulations of the 'generative systems' approach, Feldman's (2000) study of routines associated with university housing, then we can suggest what such a perspective can add to the study of organizational routines.

Feldman's study looked at routines of damage assessment, moving in, and hiring and training of staff in university housing over a four year period. Based on observation and participation, she noted that rather than the anticipated enduring character of routines, such routines exhibited considerable differences from year to year and that these 
differences in turn had impacts on those involved. Thus building directors saw their roles and the associated routines as part of the educational process, whereas central administration framed them in terms of efficiency. In examining routines for hiring and training students to act as members of teams running the halls she observes that

Central administrators saw an opportunity to create a specialist system that fit their ideal of increasing expertise for dealing with specific problems of individuals.

Building directors saw the erosion of their ability to create the kind of staff teams that they felt were necessary for the well-being of the residence halls (Feldman, 2000: 622).

This focus on the internal dynamics of routines is illuminating in pointing to the potential for change, but it seems divorced from a broader consideration of the changing roles of administrators and educationalists in the running not only of university housing but in the tertiary education system more generally. That is, her account of changing routines seems as much as anything to reflect a contending set of logics, logics which only make sense in the historical evolution of tertiary education in developed economies. The shift, for example, to mass higher education which characterizes such economies brings with it changed opportunities, not least for enhancing the perceived necessity and centrality of administrative processes. Bringing history into the analytical narrative could supply this broader context. It also, it is suggested, supports an alternative conceptualisation of organizational routines.

Our starting point is therefore with the resources and constraints provided by broader cultural and material practices that give shape and meaning to routines. In some cases those resources find formal expression in programmatic statements, so it is useful to examine 
these for their implications for organizational practices. In some cases, those organizational practices are specified in more detail in specific guidance which suggests the shape of organizations and the routines that they might adopt. A comparative treatment here which looks at the existence and extent of such guidance is valuable in pointing to differences in routine formation. That is, it focuses our attention on the means of dissemination of practices and the degree to which their details are specified. Within such different organizational forms it is then important to assess the distribution of the power to define and implement routines. On this perspective, routines are seen not just as performances but, in the words of Geoff Hodgson, as 'organizational dispositions to energize conditional patterns of behaviour within an organized group of individuals, involving sequential responses to cues' (Hodgson, 2008: 21). While patterns of behaviour are still embedded in this formulation, the attention is now placed on routines as organizational dispositions. Routines in organizations are not just therefore the creative response to particular situations (although they involve that) but they are the organizationally sanctioned response to specific cues. They may be performed slightly differently every time that they are invoked, but that performance is generally within specific parameters. It is important, as well, to consider the relative degree of involvement of particular participants and their ability to shape the ongoing performance of the routine. Together with the observations above about the importance of rules and the control of their formulation this suggests a number of ways in which we can frame routines in order to explore them historically. The next section considers why and how we might investigate routines historically.

\section{Routines and history}


It has to be accepted that if we conceptualize routines as performance and the meanings that are generated during that performance, then history can offer us little purchase. We can clearly have no observational or participatory access to the performance of past routines. Even though oral history can give us insight often missing from formal records, it is beset with all the problems of retrospective accounts. Just occasionally we might stumble across evidence which gives us a glimpse of how routines were performed. For example, here is how money was counted in a Scottish church in 1749:

The Elders after divine worship, counted what they themselves or their substitutes had collected, \& put it into the Session-Box, with a Note on a bit paper, Signifying that such a Sum was collected on such a day and then to lock the Box, on which were two locks \& two keys, to take the Keys home with them: or if they had not time to count it that evening, to put money collected wrapt up in a Napkin in the Box, and to lock it and carrying away the Keys, and to count it tomorrow or at first leisure and then to put it $\&$ a Note with in in the Box. ${ }^{1}$

However, it is more likely that we will be left with the traces of routines. Such traces can be cumulatively useful in tracking the degree to which routines were recorded over time. They might provide some insight into the evolution of a routine but, as we will see below, a historical approach is probably more valuable in showing how routines might change and adapt in the face of changing circumstances, how either routines with the same label have differing content or how similar circumstances call forth performances which have echoes of partially forgotten routines. However, possibly the greatest value to be gleaned from a historical approach is an examination of the conditions of possibility of particular performances. This involves the examination of programmatic statements of belief which 
might formally specify the practices by which they would be operationalised or, more likely, imply such practices. In some circumstances, as we shall see, those implications might be formally worked out in texts which provide guidance. However, such texts can never fully specify the rich situations in which performances take place, and so there is the need to examine the unfolding relationship between practices and beliefs over time. As Paul Veyne suggests, this is particularly valuable when carried out comparatively. 'If in order to study a civilization,' he argues, 'we limit ourselves to reading what it says itself - that is, to reading sources relating to this one civilization - we will make it more difficult to wonder at what, in this civilization, was taken for granted' (Veyne, 1984: 7). History can when conducted in this vein bring into focus that which is taken-for-granted and give us a sense of the degrees to which practices have become routine.

Of course, the term 'routine' itself has a history. While this is not the place for an extensive discussion of the etymology of the term, it would appear to have entered English from French in the mid-seventeenth century. Here it drew on the metaphor of the French 'route' for 'road', thus suggesting a constrained direction of travel. The first recorded instance was in a translation in 1661 of a French text on the organization of libraries (Evelyn, 1661: 23). The usage here is not particularly clear, but six years later William Cavendish, Duke of Newcastle, used the term in a manual on the training of horses, where he argued that a training method which advocated the accustoming of the animal to particular landmarks 'Pretends to be an absolute Method, [but] is no more than an absolute Routine' (Cavendish, 1667: 4). The use of such marks, he argued, 'is a meer Routine; that is, by Rote; because it works by the Eyes, and not by Feeling the Hand, and the Heels, and being obedient to them' (Cavendish, 1667: 3). That is, the routine is associated with mechanical performance, rather 
than creative response to changing circumstances. So this concept of routine was already available, even if the term itself is not used in guidance material. In some senses, this is not surprising. On the one hand, such guidance often lays out broad principles which tend to assume rather than label the practices by which their injunctions are to be put into effect; on the other, the concept of routines is a later analytical term which we use to understand practices which might not necessarily be labelled as such by participants. While the concept of routines is clearly drawn from contemporary organizational theorizing, using it as an analytical device to examine the past is justified if it gives us fresh ways of examining past practices, ways of seeing which might in turn help us better understand contemporary practices. The approach here draws on the example provided by the historian Keith Snell (2006), whose examination of the importance of place in nineteenth century England and Wales looks at taken for granted practices such as memorial inscriptions guided by concepts drawn from contemporary social theory.

Accordingly, the focus in what follows is on the examination of one particular practice, that of the visitation. Visitations, or inspection visits, are routines which are to be found in many contexts, from the inspection of schools to the assurance of quality in supply chains (Boyne, Day and Walker, 2002). They are often linked to expected standards of performance, set down in formal bodies of guidance which can in turn be linked to wider debates not only about those particular standards, but also about the measurement of performance more generally. Examining their religious predecessors enables us to both see a particular routine and how it changes in context, and how a routine has a history. While the focus for the purpose of this discussion is on one particular routine, that of the visitation, it will be seen that it is part of a connected web of routines. It also involves a number of actors and our 
particular focus will be on the extent to which lay actors were involved. This becomes important, it will be argued, for the degree to which the principles embodied in the routine were diffused or translated into other domains.

\section{Sources and method}

Religion is perhaps an unexpected context for this discussion, but it is one which is valuable in both having formal statements of belief which at least imply organizing routines and which provide quite different forms of such belief. The visitation routines to be examined and contrasted in what follows were those practised in pre-Reformation Catholic Italy, and in the contrasting post-Reformation Protestant polities of the Anglican Church of England and the Presbyterian Church of Scotland. These sites do not exhaust instances of visitations, but they have been examined in some empirical detail in published material, which gives us an evidence base. It is appropriate to note that this is not a symmetrical treatment, but one which emerges from detailed archival work on the Scottish context (Mutch, 2015a). This suggested the importance of setting routines in their broader organizational context and contrasting them to practice elsewhere. This was done in part, as explained below, through examination of other published work about the routine labelled 'visitation' in other religious polities.

In looking for the formal statements of belief which might have implications for routines such as the visitation the initial source was the secondary literature on Christian theology and belief. This tends not to focus strongly on organizational matters, but gives a broad indication of the weight placed on the need for formal organization. The ways in which such broad statements of belief were translated into practical advice about organizational structure and practices was investigated through analysis of contemporary printed material. 
The differential availability of such material provided insights into the degree to which different churches sought to codify their practices. The organizational structure of the different churches was obtained not only from such formal statements, but also from the structure of archival material. This material, the survival of which also gave clues as to the culture of organization that obtained in each church, was also analysed in the case of two of the churches for evidence about the ways in which visitations were conducted. Particular emphasis was placed here on indications of lay involvement in visitations.

This process was carried out in most detail for the Church of Scotland. It was in this church that the most extensive printed documents giving instructions on how the church at all levels was found. Here, a detailed textual analysis of successive guidance documents provided insight into the shaping of the routine of visitation, notably the form and nature of the questions addressed. This gave an indication of the way in which, over a fifty year period, practice was increasingly codified, with a common core of questions to be asked during visitations being laid down. In the Church of England, no such guidance was produced centrally and such printed material that was made available to guide local practice was a commercial production. The relative silence of such material on the conduct of visitations is instructive. For the Roman Catholic church reliance was placed on the secondary account produced by Bigoni et al (2013).

The nature of practice was then tested by the examination of visitation reports in the records at session, presbytery and synod level (terms explained below). It should be understood that the Scottish system paid considerable attention to detailed record keeping, meaning that an extensive archive (to the extent of some five million pages) has been preserved. This necessitated a sampling process, with the records of all eight lowland 
synods being examined at ten year intervals from 1710 to 1740 . This was followed by a more detailed examination of four presbyteries for all the years, producing a total of 133 visitations. A count of recorded visitations enabled an assessment of the prevalence of the practice over time. For each visitation, the questions asked were contrasted to those laid down in central guidance. This material allows general conclusions to be drawn for the whole Scottish system. By contrast, the evidence for the other two locations is more focused on particular areas. For England, the focus was on one group of parishes in the county of Nottinghamshire, drawing on the records of visitations which survive at central level (Mutch, 2011). This is because, in stark contrast to the Scottish situation, local record survival is very fragmentary. This in turn reflects the nature of those local records, which were always limited when contrasted to Scotland. Similarly, the Italian example focuses on one diocese, that of Ferrara, and again rests on records held centrally. Local account books have not survived, although their existence can be inferred. The sources used by Bignoni et al (2013) were therefore the central reports of visitations, particularly four books covering visitations from 1432 to 1450 , and printed rules for carrying out visitations. Although we always have to be mindful of the limitations of historical analysis, based as it is on the vagaries of record survival, enough material is produced in these accounts to enable our key aim, the comparison of the same routine in different contexts.

This comparison requires that, first of all, we consider the place of the organized church in Christian denominations. The way in which such a commitment to organization was translated into specific organizational guidance and form is then considered, which requires an outline of the different polities. This then frames a description of the different practices 
of visitation and their relationship to printed guidance. Particular attention is paid to the different patterns of lay involvement that examination of the archival material indicates.

\section{Organizational structure, guidance and visitations}

As Foucault (1997: 224) notes, the examination of religion as a social practice, as opposed to a belief system, is relatively underdeveloped. However, these three sites provide a good basis for drawing some contrasts. What is particularly important is the way that they draw our attention to the history of routines. The churches which emerged after the Reformation did not develop all their organizing routines from scratch; in many cases they took on existing practices. This continuity carried with it its own implications, as we will see. It is important also to note that the period of the so-called Reformation was not just about the emergence of Protestantism as a rival to Catholicism, but also was the site of reform movements within Catholicism. Indeed, the visitations of the medieval period can be seen in the context of reform movements. In England, the visitation of nunneries in the north of the country in the fourteenth century was a response to broader concerns about their operation (Tillotson, 1994). In Italy Bigoni et al (2013) relate visitations directly to the fifteenth century reforms of pope Eugenuis IV.

The theological differences that emerged following the work of activists such as Luther and Calvin are complex and the subject of much debate; what remains the case is that all the major Christian denominations remained wedded to the need for a church as an organized body of the faithful. Foucault notes

On the one hand there was the, let's say, Protestant type, or the type developed by different Protestant sects, with a meticulous pastorate, but one that was all the 
more meticulous as it was hierarchically supple, and on the other hand, there was the Counter Reformation with a pastorate entirely brought back under control, a hierarchized pyramid, within a strongly centralized Catholic Church (Foucault 2009: 149).

MacCulloch (2004) notes three main forms of Reformed Protestantism: the Lutheranism that characterised much of Germany and northern Europe; the Calvinism of the Netherlands and Scotland; and the Episcopalianism of England. (All of which later spread outside of these boundaries, in different forms, some of which we will touch on later). This account contrasts two of these forms (because we have work on the practice of visitation in them) with Catholicism. In all cases, the fundamental organizational unit for the church was the parish, a geographically bounded area ministered to by a clerical incumbent, variously termed the parish priest in Catholicism, the rector or vicar in the Church of England and the minister in the Church of Scotland. The Catholic visitation fitted with a strictly hierarchical form of organization, with the Pope at its apex. The Church of England carried on this hierarchical tradition, albeit with the monarch rather than the Pope at the apex. In both churches authority passed through a series of specialised offices, with bishops being key in seeking to control the activity of incumbents in the localities. That is, groups of parishes were under the oversight of specialised officials with specific authority. Those groups often consisted of large numbers of parishes, with bishops, for example, having large numbers of sub-officials between them and the incumbents. For the purpose of the current discussion those details are not elaborated on further. By contrast, the Presbyterian system which evolved in Scotland has been described as a conciliar one, with a series of bodies governing aspects of the church and the absence of a central executive (Weatherhead, 1997). An annual General Assembly, made up of delegates from the localities, made policy which was transmitted via 'presbyteries', which oversaw groups of about fifteen parishes, each of which in turn possessed their own 'session', 
chaired by the minister but consisting of between six and fifteen 'elders', to oversee local affairs. Regional 'synods', groupings of four or five presbyteries, also considered broader issues of policy and sought to ensure consistency across presbyteries. In all these systems, however, there was a strong commitment to the idea of an organized church. Calvin's comment that, 'To the government thus constituted some gave the name of Hierarchy - a name, in my opinion, improper, certainly not one not used by Scripture' is indicative of a distinctive difference between Catholic and Protestant conceptions of church governance (Calvin, 1983: 330). Protestants, especially those inspired by Calvin, sought to return to the scriptural origins of the primitive church, stripping away what they saw as the accretions of centuries. They were clear both that churches were fallible human creations but also that they were essential. John Knox, a key figure in the formation of the Church of Scotland was clear that 'We utterly abhor the blasphemy of those that affirm that men which live according to equity and justice shall be saved, what religion soever they have professed' (Knox 1905: 352). The core characteristics of a church rightly established were true preaching, right administration of Sacraments and discipline: 'ecclesiastical discipline uprightly administered, as God's Word prescribes, whereby vice is repressed, and virtue nourished' (Knox 1905: 354). At the heart of all of these polities, therefore, were concepts of discipline and accountability.

In considering the organizational framework within which these principles were worked out, however, we need to also take into account the relationship with states. Catholicism was a transnational institution, forming an alternative power centre to nation states. However, there was a considerable complementarity between its hierarchical structure and those of absolutist states, seen most clearly after the Counter-Reformation in the Iberian Peninsula. In England, the formation of the Church of England was an act of state, with the monarch, in 
the form of Henry VIII, taking the place of the Pope as head of the church. This produced numerous disputes over a period of years over both the liturgy and the organizational form of the church, but this was clearly a church established by law, with bishops sitting in the House of Lords. Such an arrangement was anathema to Scottish Presbyterians, who sought a dual authority of church and state, with each reinforcing each other but retaining control over its own sphere. Again, there were considerable struggles over the precise organizational consequences, but these factors had a key influence over lay participation, which we can see if we examine the details of visitations. Here we need to supply a brief description of the conduct of each.

\section{Visitations in practice: Italy}

In the diocese of Ferrara visitations were carried out by the bishop. An interview with the priest sought to understand his spiritual and moral conduct. Visitations were guided by a list of 26 questions, which also considered in detail the stewardship of the church's assets. The proceedings were recorded by a notary and by some related routines. If one had not already been supplied, the notary compiled an inventory of church assets. The visitation also inspected the accounts of income and expenditure which were to be kept by a 'massoro' or layman. These 'massari', selected from the wealthiest inhabitants were, say Bigoni et al (2013), a key link in the process. They were appointed by the bishop at the end of the visitation and were, 'in charge of helping the priest in taking care of the Church's properties and managing his benefice. They were also to report to the Bishop that the changes required were implemented after the visit. They were in effect the eyes and ears of the Bishops, reporting on the priest's failure to comply with his orders' (Bigoni et al, 2013: 581). 
However, in contrast to the position at the centre of the diocese, the effectiveness of this practice at local level seems to have been limited. 'In contrast to the wealth of accounting information preserved for the Bishopric,' comment Bigoni et al (2013: 584), 'at the local village level no parish account books appear to have survived, even though the minutes of the pastoral visits often refer to the liber introituum et expensarum ("book of incomes and expenses")'. Of course, this could reflect the vagaries of record survival, but that survival in itself, as we shall see, is an important indicator of the success of an overall system of accountability as opposed to individual practices. We also lack detail on just how effective the massari were in their surveillance capacity, as these visitations seem to have been limited to a reforming spurt of activity.

\section{Visitations in practice: England}

In eighteenth century England the visitation also featured as a putative mechanism of discipline, but its effectiveness was of considerable doubt. As in the Catholic tradition, lists of questions were supplied by bishops. Sometimes they visited their parishes in person, but much of the process was devolved to archdeacons, clerical functionaries responsible for a group of parishes. They called meetings of churchwardens. Each parish had (usually) two churchwardens, generally elected annually but sometimes serving for longer periods of office (Tate, 1983). They were to respond to the questions asked of them and to 'present' those who had offended against church discipline. Several writers on the church in the eighteenth century have commented on the ineffectiveness of church discipline as expressed in the annual archdeacon's visitations. They note the frequent recording of 'omnia bene'['all is well'] in churchwardens' returns to the questions posed by archdeacons before their visitations (Spaeth, 2000: 64-72; Gregory and Chamberlain, 2003: 160, 183, 
232). William Cole, vicar of Bletchley in Buckinghamshire, was scathing of his archdeacon, recording after the visitation dinner in 1766 that he, 'ended, most quaintly, (in the State of the Church-Wardens' Presentments, to which he alluded), that he was very glad to find, as he hoped he always should do, That All was well' (Stokes, 1931: 34). In 1740 only four parishes in the Bingham deanery of Nottinghamshire presented any offenders for consideration, all mothers of illegitimate children (Mutch, 2011). There were good reasons for churchwardens failing to present, notably the opprobrium they might face in small rural communities if they presented any other than the relatively defenceless or particularly outrageous. In addition, surviving records of their local activities are rare, with most of the records that do survive being accounts of sums raised and expended. These are in a variety of formats, often containing very little detail. The visitation in this context had much of the character of a ritual, with accountability practices being largely exercised at the local level and heavily dependent on local custom and tradition.

\section{Visitations in practice: Scotland}

By contrast, there was a concerted effort in Scotland to lay down a process of parish visitation. This can be found from the founding documents of the church. In other words, the new church took on aspects of existing practices but, unlike in England, where there was a strong sense of continuity with many practices, they sought to give them new content. Of particular importance was the stress on the written record, both of decisions taken and of financial transactions made (Mutch, 2012). Visitations, which were made by physical visit of members of the presbytery to a parish, used these records as part of their evidence. They also asked a series of questions to the minister, the elders who formed the kirk session, and members of the congregation. The crucial element here was the corporate nature of the kirk 
session. Composed of between six and fifteen members (depending on the size of the parish) this group of men (they were always men) was selected by their predecessors in office but open to objection from the congregation. Once in office they served for life, so giving the lay voice an organizational form which did not exist in the other two polities. Another distinguishing feature was the efforts made in the Scottish case to lay down books of guidance which specified the nature of the questions to be asked and the supporting routines. Considerable attention was paid to the format of the records to be retained, down to suggestions about an archiving process.

The guidance issued in 1704 suggested that visitations ought to be part of a designed programme, in which all churches were to be visited once a year, or 'at least this ordinary visitation should be going round all the parishes in order, till they be visited, before others be revisited in ordinary'. (That is, provision was also made for visitations to tackle extraordinary situations) (Church Law Society, 1843: 358). In practice, this was never achieved. The highpoint of the Scottish system was in the first twenty years of the eighteenth century, but even here implementation was patchy. The reasons for it fading out could be several. For some commentators the problems it created outweighed the value. 'These inquisitions,' argued one, 'did vastly more harm than good. They were dangerous weapons to put in the hands of every malcontent who had a grudge to gratify or a fanatical grievance to express, with the risk of making a clergyman's life a burden to him and his congregation a terror' (Graham, 1899: 334). However, an alternative interpretation to their gradual demise could see them as having served their primary purpose. If that purpose is seen as the imposition of orderly presbyterian government and, especially, the creation of a disciplined ministerial cadre, then it is arguable that the early years of the eighteenth 
century, when visitations were at their peak, saw a measure of success. It could also be that visitations were simply impractical. The framers of the guidance just failed to take into account the sheer press of business, imagining a system without recalcitrant landowners (those responsible for expenditure on the church fabric) and ministers with human failings.

\section{Lay involvement and the shaping of the visitation}

The routine that was the clerical visitation, then, met with limited success in each of these different church polities. It was often associated with a burst of reforming zeal, which with the passage of time either became unsustainable or took on the characteristics of a ritual.

What is important is that the routine had a history and was not just emergent from patterns of activity. It was subject to local interpretation, but such interpretation took place within a framework provided by central belief and organization. Two key factors are suggested by the three instances examined above. One is the connection of routines with other tools and technologies. In the Italian case the written record was compiled outside the local situation by a specialised actor. Local records are inferred but their failure to survive outside urban contexts might suggest something about the thoroughness with which they were kept. In England the record was held centrally and took a standard form which lent itself to ritual completion. Any locally held records were fragmented in nature and heavily conditioned by custom. In Scotland records were kept in considerable detail at several levels of the organisation and checks were put in place to ensure that this happened. The second factor is the degree of lay involvement in these routines. In the Catholic system considerable attention might be paid to laying down routines, but these were often operated by members of the hierarchy. In another example, Quattrone (2004) gives us details of practices within the Jesuit order which involved accountability practices, but those involved 
were all internal to the order. The involvement of the lay in the Ferrara visitations is an exception to this, but, from the evidence presented, it was an involvement which had no organizational form. There was a little more organizational structure in the English case, but it was again heavily subject to the influences of custom. In particular, involvement was episodic rather than enduring. The distinctive feature of the Scottish context was the enduring, corporate, nature of church bodies, which enabled the evolution of processes of detailed record keeping.

Where this is important is in broader influence. What we can see is the same routine occurring in very different polities, inflected by the broader features of that polity. In the Catholic examples the influence appears to have been a largely internal one, given the restricted role for lay influence on the church hierarchy. Routines, that is, stayed within the confines of the church. In the Church of England, the local and customary nature of lay involvement meant that visitations stayed at the level of ritual. By contrast, the Scottish visitation was part of a broader complex of accountability. Not all aspects of this worked effectively, but there was sufficient lay involvement to suggest a route to broader diffusion. There are a number of markers of this. By the end of the eighteenth century a dense network of connections through trading and settlement linked Scotland and the nascent United States of America (Murdoch, 2010). Interwoven with these were spiritual connections, with considerable transatlantic exchange of both ideas and personnel. Presbyterianism proved a powerful form of organizing template for frontier communities and in this effort American Presbyterians evolved their own tradition of 'books of order', which drew heavily on Scottish exemplars. In this, they drew on Scottish traditions of detailed record keeping, accompanied by the domination of the market for accounting 
textbooks by Scottish authors (who in turn were strongly connected to the Church of Scotland) (Mepham,1988). This fostered what Peter Dobkin Hall has called a 'culture of organization', in which Protestant evangelicals played a key part. 'This subculture of individuals,' he writes, 'trained to autonomy and accommodated to modes of corporate and proto-bureaucratic activity, would prove of immense importance not only in organizing the Civil War mobilization but also in creating and staffing the large-scale organizations that emerged after the war' (Hall, 1992: 33). As a specific example, Alfred Chandler, doyen of American business historians, reproduced the work of the Scottish cotton mill manager James Montgomery in a volume entitled Precursors of Modern Management (Chandler, 1979). Montgomery, son of a Scottish cotton worker and committed Presbyterian, published his Carding and Spinning Master's Assistant in 1832 before moving to the United States to manage a number of cotton mills. In similar vein, Chandler (1977: 101) suggested that Daniel McCallum, railroad engineer and manager from a similar confessional background to Montgomery, was the originator of the organization chart and so of systemic management practices.

\section{Conclusion}

Our analytical narrative of the emergence of the routine of the visitation, limited though it is both by the nature of the evidence and by the space available for exposition, confirms the gap between the attempt to lay down rules for the exercise of routines and the operationalisation of those rules in practice. However, the broader perspective given by a historical account restores the balance between the necessarily creative performance of routines in specific contexts and the enduring parameters within which that creativity is performed. Our second critique was that the meanings attached to routines are more than 
those generated during performance. Sewell's focus on the rules conditioning the use of resources is exemplified by Scottish attempts to make visitation work. They were more thorough-going than the other churches in a way which indicates something of the importance attached to order as a good in its own right in that church. In this they drew on an enduring tradition, crystallized in guidance manuals, of specifying organizational practices in detail in systematic fashion. This in turn addresses the third aspect of the critique presented above, the detaching of routines from their broader context. The attention paid above to the differential impact of organizational structures to the fate of the visitation routine reinforces the importance of examining the nature of such structures and their supporting theories. All the churches examined paid attention to ecclesiology, that is, to the consequences for church organization of theological precepts, but the results were different with important consequences for the operation of routines. Both the Roman Catholic Church and the Church of England adhered to a hierarchical model which gave little or no space for lay involvement. This tended to produce either the early failure of routines or their survival as rituals. By contrast, the greater scope for lay involvement in the relatively more decentralized (but still hierarchical) Church of Scotland meant that routines were more enduring. Of still more significance was the potential for the routine to migrate from its original setting to other domains, given its status as a taken-for-granted organizing practice.

Of course, religious movements tend to produce formal statements of belief which may make elucidation of the logics that give shape and meaning to routines much easier. However, what the examination of visitations in historical perspective suggests is the importance of means of dissemination, ways in which what is often assumed in broader 
statements of belief is translated into specific guidance for practice. This would support those who stress the importance of examining the shaping role of standard operating procedures in the context of organizational positions (D'Adderio, 2008). Such guidance can never be exhaustive given the innovation inherent in open systems, but it can provide clues as to the status of organizing as a good in its own right. What is particularly valuable in a historical approach is the ability to make comparisons. This can show up absences, absences which would not be apparent from a focus on performance.

Feldman and Pentland (2003: 95) remind us that routines are performed 'by specific people, at specific times, in specific places' . However, this injunction is restricted to, as it were, an internal perspective on routines, where the specification of those terms is limited to the performance of the routine. As Essén (2008: 1637) argues, 'the performance of routines is shaped by factors beyond the routine itself, and beyond the organization in question'. History provides us with one way of addressing these wider factors. This is not to downplay the value of thick descriptions of performance, but to suggest that they need to be supplemented by accounts which place that performance in historical context, showing how performance is shaped by factors which are beyond the immediate control or even knowledge of the participants. History provides us with diachronic accounts of the development of such factors, but it is not claimed that there are not other valuable approaches. Synchronic accounts which factor in the impact of broader theories present at the same time as the performance of routines are another way to correct a focus on unconstrained performance (D’Adderio and Pollock, 2014).

To the historian, the survival of documents can itself be an important pointer to the character of organizational life. The survival of documents which were products of routines 
and never intended to pass comment on the content or performance of routines is often seen as shedding more light than more discursive accounts. Given the widespread inscription of routines into information and communication technology artefacts in contemporary organizations, which produce extensive data as a routine part of their operation, this point drawn from historical practice suggests support for those who urge greater attention to the comparative analysis of such traces (Pentland et al, 2009).

Routines, therefore, have a historical context; they also have a history. Although examination of it has not been attempted here, the Church of Scotland continues to have a routine labelled as 'visitation', albeit with considerably different content to those examined here. It would be feasible to trace this changing history, which is related to practical experience with what works, to changes in theology and to changes in prevailing cultural norms. Such possibilities might suggest that students of contemporary routines push back their enquiries to see if their objects of study have a past, either in the focal organization or in the relevant context. Of course, we have to recognize the limitations of historical analysis. It cannot provide us with the rich insights into the inner lives of routines that ethnographic inquiry affords. Even using the tools of oral history gives us only retrospective accounts, coloured as they are by the fragility of human memory. The historian is limited to the traces that have been left, which are often shaped by accident and which can privilege certain actors and the accounts they have left. For the historian, it is the survival of mundane documents generated by the routines themselves, rather than representations of the routines, which can be particularly valuable. They enable, especially when examined in comparative fashion, the gleaning of connections which might not have been available to the participants at the time. Granted these limitations, historical analysis still has an 
important part to play in supplying evidence which speaks to the stability of routines and their connectedness to wider social practices. In this way, it forms a valuable counterweight to accounts which focus solely on performance. 


\section{References}

Archer, M. (1979) Social origins of educational systems, London: Sage.

Archer, M. (1995) Realist social theory: the morphogenetic approach, Cambridge, UK:

Cambridge University Press.

Archer, M. (1996) Culture and agency: the place of culture in social theory, Cambridge, UK:

Cambridge University Press.

Becker, M. (ed), (2008) Handbook of organizational routines, Cheltenham, UK: Edward Elgar.

Becker, M. and Lazaric, N. (eds) (2009) Organizational routines: advancing empirical

research, Cheltenham, UK: Edward Elgar.

Bigoni, M., Gallardo, E. and Funnell, W. (2013) Rethinking the sacred and secular divide:

accounting and accountability practices in the Diocese of Ferrara (1431-1457), Accounting,

Auditing and Accountability Journal, 26(4), 567-594.

Birnholtz, J., Cohen, M. and Hoch S. (2009) Is it the same ? observing the regeneration of organizational character at Camp Poplar Grove, in Becker, M. and Lazaric, N. (eds)

Organizational routines: advancing empirical research, Cheltenham, UK: Edward Elgar, 131158.

Boyne, G., Day, P. and Walker, R. (2002) The evaluation of public service inspection: a theoretical framework, Urban Studies, 39(7), 1197-1212.

Cavendish, W. (1667), A new method, and extraordinary invention, to dress horses, and work them according to nature, London, UK: Thomas Milbourn.

Chandler, A. (1977) The visible hand: the managerial revolution in American business, Cambridge, MA: Harvard University Press. 
Chandler, A. (ed) (1979) Precursors of modern management, New York: Arno Press.

Church Law Society (1843) Acts of the General Assembly of the Church of Scotland 16381842, Edinburgh, UK: Church Law Society.

Clark, A. (2004) Testing the two modes theory: Christian practice in the later Middle Ages, in Whitehouse, H. and Martin, L. (eds.) Theorizing religions past: archaeology, history, and cognition, Walnut Creek CA: AltaMira Press, 125-142.

D Adderio, L. (2008) The performativity of routines: theorising the influence of artefacts and distributed agencies on routines dynamics, Research Policy, 37, 769-789.

D’Adderio, L and Pollock, N. (2014) Performing modularity: competing rules, performative struggles and the effect of organizational theories on the organization, Organization Studies, 35(12), 1813-1843.

Dionysiou, D. and Tsoukas, H. (2013) Understanding the (re)creation of routines from within: a symbolic interactionist perspective, Academy of Management Review, 38(2), 181205.

Elias, N. (2000) The civilizing process: sociogenetic and psychogenetic investigations, Oxford: Blackwell.

Essén, A. (2008) Variability as a source of stability: studying routines in the elderly home care setting, Human Relations, 61, 1617-1644.

Evelyn, J. (1661) trans of Gabriel Naudeus Instructions concerning erecting of a library presented to my Lord President de Mesme, London, UK: G. Bedle.

Feldman, M. (2000) Organizational routines as a source of continuous change, Organization Science, 11(6), 611-629. 
Feldman, M. and Rafaeli,A, (2002) Organizational routines as sources of connections and understandings, Journal of Management Studies, 39(3), 309-331.

Feldman, M. and Pentland, B, (2003) Reconceptualizing organizational routines as a source of flexibility and change, Administrative Science Quarterly, 48, 94-118.

Felin, T. and Foss, N. (2009) Organizational routines and capabilities: historical drift and a course-correction toward microfoundations, Scandinavian Journal of Management, 25(2), 157-167.

Foucault, M. (1997) Ethics, subjectivity and truth, (ed. Paul Rabinow, vol 1 of essential works), New York, NY: The New Press.

Foucault, M. (2009) Security, territory, population: lectures at the Collège de France 19771978, Basingstoke, UK: Palgrave Macmillan.

Friedl, M amd Larty, J (2012) Replication of routines in organizations: existing literature and new perspectives, International Journal of Management Reviews, 15, 106-122.

Golsorkhi, D., Rouleau,L, Seidl, D. and Vaara, E. (2010) Cambridge handbook of strategy as practice, Cambridge, UK: Cambridge University Press.

Gregory, J. and Chamberlain, J. (2003) The national church in local perspective : the Church of England and the regions, 1660-1800, Woodbridge, UK: Boydell.

Hall, P. (1992) Inventing the nonprofit sector and other essays on philanthropy, voluntarism and nonprofit organizations, Baltimore, MD: John Hopkins University Press.

Helin, J., Hernes, T., Hjorth D., and Holt, R. (2014) The Oxford handbook of process philosophy and organisation studies, Oxford, UK: Oxford University Press. 
Hodgson, G. (2007) Institutions and individuals: Interaction and evolution, Organization Studies, 28(1), 95-116.

Hodgson, G. (2008) The concept of a routine, in Becker, M. (ed) Handbook of organizational routines, Cheltenham, UK: Edward Elgar, 15-28.

Howard-Grenville, J. (2005) The persistence of flexible organizational routines: the role of agency and organizational context, Organization Science, 16(6), 618-636.

Ingvaldsen, J. (2015) Organizational learning: bringing the forces of production back in, Organization Studies, 36(4), 423-444.

Knox, J. (1905) The history of the reformation of religion in Scotland by John Knox; with which are included Knox s Confession and The book of discipline, London, UK: Melrose.

MacCulloch, D. (2004) Reformation: Europe's house divided 1490-1700, London, UK: Penguin.

Mepham, M. (1988) Accounting in eighteenth century Scotland, New York, NY: Garland.

Murdoch, A. (2010) Scotland and America c. 1600 - c. 1800, Basingstoke, UK: Palgrave MacMillan.

Mutch, A. (2011) Custom and personal accountability in eighteenth century south Nottinghamshire church governance, Midland History, 36(1), 69-88.

Mutch, A. (2012) Systemic accountability and the governance of the Kirk: the Presbytery of Garioch in the eighteenth century, Northern Scotland, 3, 45-65.

Mutch, A. (2015a) Religion and national identity: governing Scottish presbyterianism in the eighteenth century, Edinburgh, UK: Edinburgh University Press. 
Mutch, A. (2015b) 'Pastoral power and governmentality: from therapy to self help', Journal for the Theory of Social Behaviour, doi10.1111/jtsb.12099, 1-18

Nelson, R. and Winter, S. An evolutionary theory of economic change, Cambridge, MA: Harvard University Press, 1982.

Nicolini, D. (2009) Zooming in and out : studying practices by switching theoretical lenses and trailing connections, Organization Studies, 30(12), 1391-1418.

Oxford English Dictionary (2011) Routine, http://www.oed.com/, [accessed 17 March 2015] Pentland, B. and Feldman,Martha, (2005) Organizational routines as a unit of analysis, Industrial and Corporate Change, 14(5), 793-815.

Pentland, B. and Feldman, M., (2008) Designing routines: on the folly of designing artifacts, while hoping for patterns of action, Information and Organization, 18, 235-250.

Pentland, B., Haerem, T. and Hillison, D. (2009) Using workflow data to explore the structure of an organizational routine, in Becker, M. and Lazaric, N. (eds) Organizational routines: advancing empirical research, Cheltenham, UK: Edward Elgar.

Reynaud, B. (2005) The void at the heart of rules: routines in the context of rule-following. The case of the Paris Metro Workshop, Industrial and Corporate Change, 14(5), 847-871. Quattrone, P. (2004) Accounting for God: accounting and accountability practices in the Society of Jesus (Italy, XVI-XVII centuries), Accounting, Organizations and Society, 29, 647683. 
Rerup, C. and Feldman, M. (2011) Routines as a source of change in organizational schemata: the role of trial-and-error learning, Academy of Management Journal, 54(3), 577610.

Rowlinson, M, Hassard, J. and Decker, S. (2014) Research strategies for organizational history: a dialogue between historical theory and organization theory, Academy of Management Review, 39(3), 250-274.

Snell, K. (2006) Parish and belonging: community, identity and welfare in England and Wales, 1700-1950, Cambridge, UK: Cambridge University Press.

Spaeth, D. (2000) The Church in an age of danger: parsons and parishioners, 1660-1740, Cambridge, UK: Cambridge University Press.

Stokes, F. (1931) The Blecheley diary of the Rev. William Cole, 1765-67, London, UK: Constable.

Tate, W. (1983) The parish chest: a study of the records of parochial administration in England, Chichester, UK: Phillimore.

Tillotson, J. (1994) Visitation and reform of the Yorkshire nunneries in the fourteenth century, Northern History, 30, 1-21.

Turner, S. and Rindova,V. (2012) A balancing act: how organizations pursue consistency in routine functioning in the face of ongoing change, Organization Science, 23(1), 24-46.

Ventresca, M. and Kaghan,W. (2008) Routines, going concerns and innovation: towards an evolutionary economic sociology, in Becker, M. (ed.) Handbook of organizational routines, Cheltenham, UK: Edward Elgar 52-86. 
Veyne, P. (1984) Writing history: essay on epistemology, Manchester : Manchester

University Press.

Weatherhead, J. (1997) The constitution and laws of the Church of Scotland, Edinburgh, UK:

Church of Scotland.

Wright, A. (2014) Organizational routines as embodied performatives: A communication as constitutive of organization perspective, Organization, .

Zbaracki, M. and Bergen,M. (2010) When truces collapse: a longitudinal study of priceadjustment routines, Organization Science, 21(50, 955-972.

${ }^{1}$ National Records of Scotland, Edinburgh, CH2/415/1 Cambuslang session minutes and collections 1658-1788, 1749, 235. 